\title{
KÖTETLEN KALANDOZÁSOK KÉMIAORSZÁGBAN
}

A kémia hasznos és érdekes tudomány. Ez a mondat alighanem minden vegyész számára magától értetődő, de a társadalom zöme számára egyáltalán nem az. A kémia szó a legtöbbekben a közoktatásbeli kémiaórák emlékeit idézi fel, s ezek az esetek döntö többségében sajnos a legkevésbé sem kellemesek.

Ezért is kell nagyon megbecsülni azt, ha egy vegyészprofesszor müveltségét és írói tehetségét a tudomány népszerüsítésének szolgálatába állítja, és megpróbálja megmutatni másoknak is a kémia szépségét, eredményeinek hatalmas hatását mindennapjainkra. Magyarországon ijesztően kevesen foglalkoznak ezzel: a néhai Beck Mihály akadémikus példája sajnos nem bizonyult ragadósnak, nyomában legfeljebb Hargittai Magdolna, Hargittai István, Inzelt György és Schiller Róbert járnak. És persze Braun Tibor, aki talán a legtöbb ilyen publikációt jelentette meg az elmúlt években.

A tudomány-népszerüsítő írások magyarul ritkán születnek könyvként: az elsődleges megjelenési hely általában valamely folyóirat vagy esetleg internetes portál. Itt mindig alkalmazkodni kell a jellemző olvasóközönség összetételéhez, illetve a különböző cikkek természetesen nem támaszkodhatnak egymásra, önállónak kell lenniük. Ha az olvasók megkedvelik a szerző stílusát, akkor manapság szinte elkerülhetetlen, hogy előbb-utóbb ezt a tényt egy könyvkiadó is észrevegye, s a korábban született, változatos helyeken megjelent írásokat egy kötetbe szerkesztve adja ki. Braun Tiborral ez már másodszor fordul elö: A Nobel-díjra érdemes taxisofór címü gyüjteményének 2015-ös megjelenése után máris itt a folytatás $A$ könyvek illata címmel. S hogy a történet teljesebb legyen: ugyancsak 2018-ban jelent meg Vándorbottal a tudományos kutatásban címü interjúkötete is, amelyben hazai természettudósokkal készített interdiszciplináris villáminterjúkat kötött egy csokorba.

Tagadhatatlan bizonyítékok mutatják, hogy a kémikus olvasóközönség megszerette a szerző stílusát. A könyvek illata kötet cikkeinek jelentős része eredetileg a Magyar Kémikusok Lapjában jelent meg. A folyóirat szerkesztősége minden évben szavazásra kéri olvasóit, hogy az általuk legjobbnak ítélt cikkek szerzőjét díjazhassa. Ezen díj alapítása óta még nem fordult elö, hogy Braun Tibor legalább egy írása ne lett volna a legnépszerübb három között. Nagyon remélem, ez a szeretet nyilvánul meg majd a szerző felé a szélesebb olvasóközönség felöl is.

A most megjelent gyüjtemény hat fejezetbe csoportosítja az egyenként tíz-tizenöt oldalnál nem hosszabb, igen bőséges irodalomjegyzéket is tartalmazó írásokat. Az első címe Robbanás, csillogás, az ebben szereplö hat cikk közül négyben is központi szerepet játszanak a gyémántok, legyenek akár alig nanoméretủek 
vagy gyémántüllő-cellák kivételesen nyomásálló anyagai, noha Braun Tibor a szokásos magyar megnevezés helyett inkább a talán még jobban is hangzó 'gyémántsatu' kifejezést választotta a készülék megnevezésére. Az első fejezet első írásának címe azonos a könyvével: a könyvek illatáról szól. A vadonatúj könyvek illata sok lelkes olvasóra van inspiráló hatással, míg a régi könyvek illata méltóságteljes könyvtári hangulatot teremt bennük. Ki gondolta volna, hogy ma már a hatásért felelös vegyületek is ismeretesek?

A Dimenziók címet viselö, sorrendben második fejezet egy kétdimenziós anyag, a grafén kémiájának bemutatásával kezdődik, majd szén kvantumpötytyökről szóló írással folytatódik. A többi cikk kapcsolatát a fejezetcímmel már nehezebb látni: ionos folyadékokról, a Pickering-emulziókról olvashatunk bennük, illetve - a szerző tudománymetriára is kiterjedő kutatási tevékenységét ismerve nem meglepő módon - találunk benne közlemények hivatkozási sajátságairól szóló elemzést, majd a nanorészecske-kutatás két, egymással ritkán egyetértő, meghatározó alakja közötti nyilvános levélváltás magyar fordítását.

A harmadik fejezet címe Sártekénk, rajta és alatta. A második fejezethez hasonlóan ez is egy szénmódosulatról szóló írással indul, csak ebben az esetben kettő helyett három a dimenziók száma, mert a néha molekuláris focilabdának is nevezett fullerénekről van szó. Ezután megismerhetünk néhány kémiai tárgyú szabadtéri szobrot, majd részletes elemzést olvashatunk arról a kevésbé látványos, de a mai technológiát annál súlyosabban érintő, elsősorban politikai-földrajzi eredetủ problémáról, amelyet a világ ritkaföldfémekkel való ellátása jelent. Ezután négy tudománytörténetre koncentráló írás következik, az első az indigókémiáról, majd kettő a nevezetes maláriaellenes gyógyszer, az artemizinin felfedezéséről, végül a Cserenkov-sugárzás felfedezésének bizarr hátteréről. Hogy ez a fejezet keretbe záródjon, az utolsó, biobányászati jelenségeket és lehetőségeket bemutató írás az első fejezetben szereplő utolsó, bioásványosodásról szóló cikkel van szoros kapcsolatban.

A negyedik fejezet a legegységesebb, címe Gasztrokémia. A tudományos kutatási terület világhírú múvelői, Kürti Miklós és Hervé This nyomán itt szó esik az ötödik alapízről, az umamiról, a nyereg alatti húspuhítás legendájáról és az Alpokban talált több ezer éves, mumifikálódott holttest, Ötzi utolsó vacsorájáról. Az is garantálható, hogy a könyv olvasása után a whisky (Vagy whiskey? Ki tudja? A szerző igen.) és a csokoládé rajongói is egészen más szemmel nézik majd kedvenc italukat, illetve édességüket.

A már csak három írást tartalmazó, Felfedezés, találmány címü fejezet az ötödik a sorban. A szobrokkal kapcsolatos korábbi, képzőmüvészeti kitérő után most az irodalom és a tudomány határmezsgyéjének megismerésében vehet részt az olvasó nem kisebb lángelme, mint Karinthy Frigyes egyik írásának elemzése révén, aki azt fogalmazta meg, hogy váratlanul kicsi az emberi világ: két tetszőleges ember között legfeljebb öt személyes ismeretségen keresztül mindig kapcsolatot 
lehet találni. Ezt később hálózatelméleti kutatásokkal is bizonyították. Szó esik még a Takátsy-féle mikrotitrátorról, illetve a mikrofluidika diadalútjáról.

Habár az írások sokszínüsége miatt a korábbi fejezetcímek is nagyon szabadon értelmezendők, így is maradt a végére két cikk, amelyet egyik korábbi fejezetbe sem sikerült beilleszteni, így jobb híján az Egyebek fejezetcímet kapták. Az első az ideggázokról szól, a 2018-as évben a hírekben sokat szereplö novicsok adott szomorú aktualitást neki. A másik cikkből a szerzőt ismerhetjük meg valamenynyire: Silberer Vera beszélget vele, elsősorban folyóirat-alapítói tevékenységére koncentrálva.

Noha a kötetbe foglalt írások eredeti megjelenési helyei között a Magyar Tudomány és a Természet Világa is előfordul, döntö többségében ez a Magyar Kémikus Lapja volt, vagyis az írásokat eredetileg a kémiában jártas olvasóközönségnek szánta a szerző. Ez a tény néhány esetben alighanem gondot okoz majd olyan olvasóknak, akik valóban csak az ismeretterjesztő érték kedvéért veszik kezükbe a könyvet. Talán a korábbi cikkek egy kötetbe gyüjtése alkalom lehetett volna arra is, hogy ilyen szempontból egy kis szerkesztői munkát végezzenek rajtuk, illetve kiegészítsenek néhány olyan irodalmi hivatkozást, amely a Braun-cikk eredeti közlésekor még megjelenés alatt lévő munkákra szólt, így az adatok nem teljesek. Talán az sem túl szerencsés, hogy a különböző folyóiratokba azonos témáról írt, jelentős átfedéseket tartalmazó cikkek (például a nanogyémántokról vagy az artemizininről) változatlanul szerepelnek a kötetben. Ennek ellenére nem lehet kétség afelöl, hogy értékes mủvet kapott ezzel a könyvvel a magyar olvasóközönség.

A könyv előszavában a magyar ismerterjesztő irodalomban is nagy névnek számító fizikus akadémikus, Kroó Norbert méltatja a szerző sokoldalúságát és az írások élvezhető nyelvezetét. Talán nem illetlenség ezt a könyvismertetését az ő utolsó gondolatával zárni. „Az olvasó olyan intellektuális kalandok részese lehet, amelyek tudásnövelö, látókör-szélesítő és eligazodás segítő hatásuk miatt csak javára válhatnak."

(Braun Tibor: A könyvek illata. Írások a nanogyémántokról, a csokoládéról és egyéb kémiai érdekességekröl. Budapest: Typotex Kiadó, 2018, 424 o.)

Lente Gábor

egyetemi tanár

Pécsi Tudományegyetem, Általános és Fizikai Kémiai Tanszék 